\title{
Examining the Effectiveness of E-Commerce among SME's In Polokwane, South Africa
}

\author{
*Motshedisi Elizabeth Molapo \\ Department of Business Management, University of the Free State, QwaQwa Campus, \\ Private Bag X 13, Phuthaditjhaba: South Africa. \\ Email: molapome@qwa.ufs.ac.za
}

Doi:10.5901/mjss.2014.v5n23p459

Abstract

New technologies such as the World Wide Web (WWW) of the internet have allowed organizations to advertise and sell their products and services to a global target audience at a much lower cost than traditional retailing. It also discusses the nature of both forms of business and explains a new approach which provides organizations with the opportunity to sell online to enable them to reach increasingly fragmented consumer audience in South Africa more effectively. This article attempts to address the importance of electronic commerce on small businesses in Polokwane, and to provide information on the impact of ecommerce in South African society in general. This research paper also addresses why traditional businesses will not necessarily become obsolete. Both traditional and online forms of business are compared in this project to indicate which form of business is still preferred by organizations today. The paper employed a quantitative research approach and a purposive sampling technique to achieve its objectives.

\section{Introduction}

The internet's growth rate has far surpassed the growth rates of any previously introduced electronic information dissemination mediums. Figure 1.1 compares the length of time that it took for radio, television, and personal computer to reach 50 million people as compared to the internet. In only four years after it was opened "to the public" the internet was able to reach 50 million people, which is just a fraction of the time it took for radio, television, and personal computer to reach the same usage (Greenstein \& Feinman, 2002: 6).

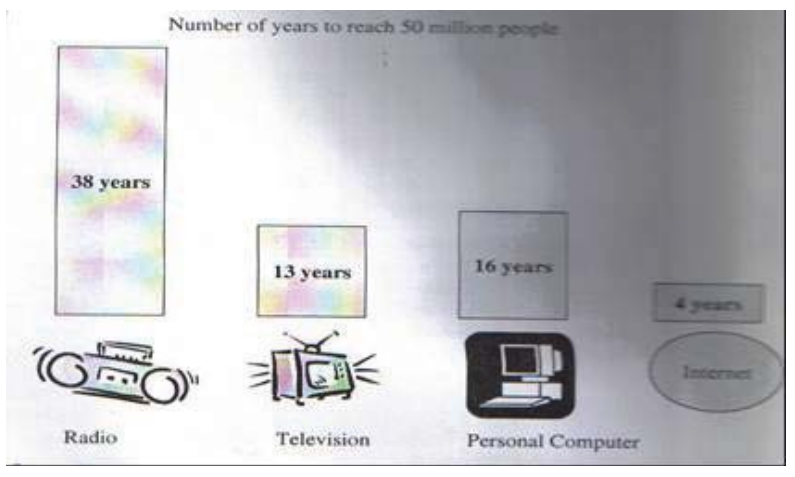

Figure 1.1 (Greenstein \& Feinman, 2002:6)

The internet is a very unique infrastructure in that it is "owned" by no one. The internet is a network of networks. The internet came on-line in 1969 as a joint project between the Defense Advanced Research projects Agency (DARPA) and four university host computers. In the early 1980s, the commercial sector became increasingly interested in the internet and began to funnel resources into commercial internet uses. The WWW was not prototyped until 1990, when Tim Berners-Lee implemented his groundbreaking concepts and became known as its father. The invention of the World Wide Web (WWW) was not related to e-commerce at all. The story began at the European Particle Physics Laboratory called CERN where physicists around the world gathered to conduct research on nuclear physics (Tanenbaum, 1996:38). Nowadays, the web system together with the internet forms the basic infrastructure for supporting e-commerce. 
Although electronic data interchange (EDI) and electronic fund transfer (EFT) have been around since the early 1970s, they were limited in their effects to encompass a whole set of marketing factors because of their high cost and technological complexity. However, recently, the rapid diffusion of the internet and World Wide Web has made conducting business over the internet much more popular. In the year 2002, the value of goods and services traded via the internet is likely to exceed $\$ 300$ billion, and is likely to exceed $\$ 1$ trillion in the year 2007. Seeing such an optimistic prediction, it is safe to predict that e- commerce has a huge potential in delivering business activities through the internet and www. Although it is unclear to predict whether e-commerce will become a substitute for the traditional marketing or will be used to complement the traditional way of doing the business.

It is also predicted that current losses in online business will, sooner or later, turn into profits once more advanced application technologies and infrastructure become available, and as more consumers become educated in the use of this new medium to enhance the qualities of their life. Since online business will never replace traditional business, an integrated approach by marketers and advertisers appears to be the best solution. Therefore the objective of this paper is to investigate the importance of e-commerce on small businesses in Polokwane. The investigation adopts a case study research design in which purposive sampling technique is used. Results reveal that high cost, limited funds and lack of technological know-how are barriers in revealing the importance of e-commerce in small business.

According VerSign, e-commerce was born on August 11, 1994, when a sting CD was sold by NetMarket. Having just celebrated its ten year anniversary in 2004, e-commerce is still going strong but the industry is in a different place than it was ten years ago. Electronic commerce is defined by the dynamics of the internet. Turban et al., (2002:4) define e-commerce as the exchange of information across electronic networks at any stage in the supply chain, whether within the organization, between business and consumers or between public and private sectors. Electronic commerce "ecommerce" is changing our economy and affecting all aspects of business. Today, no company can afford to ignore ecommerce. (Chan, Lee, Dillon, Chang, 2001:390). Society witnessed a seismic shift in communication. The introduction of newspapers and magazine that utilize text and image, radio that utilize audio, television that uses video, direct mail that utilize text and image, telemarketing that utilize audio have all transformed the way people interact with each other and have created new business opportunities and business model. Therefore, the internet provides a new media that can mix text, audio, images, graphics, animation, and video. The most popular component of the internet is the WORLD WIDE WEB (WWW) there are other features as well that offer potential to marketers, but it is the Web that has developed as the commercial component. The WWW or simply the Web is the hypertext-based graphical interface to worldwide resources. The Web is therefore the basis of another shift in the way people interact, wherever they are in the world (Belch \& Belch, 2001:486).

The internet is the engine of this shift and electronic commerce (e-commerce) is its fuel. According to many scholars and theorists of the internet, this new communication medium is the greatest and most significant achievement in the history of humankind and has changed the world within couple of years, changed both civilization and communication (Gates, 1995:23). The internet and the Web provide the enabling mechanisms to foster the growth of electronic commerce (Greenstein \& Feinman, 2000:2) nowadays, the Web system together with the internet forms the basic infrastructure for supporting e-commerce (Chan et al., 2001:39).

Having just celebrated its ten year anniversary in 2004, e-commerce is still going strong but the industry is in a different place than it was ten years ago. The emergence of e-commerce is creating fundamental changes to the way that business is conducted. These changes are altering the way in which every enterprise acquires wealth and creates shareholder value (Chung, Jackson, \& Grover, 2002:13). Customer service can be enhanced using the internet electronic commerce by helping the customer to access information before, during, and after the sale. The scholars argue that the convenience of shopping from home allows consumers to shop when it is convenient for them and not during the store hours. For handicapped or ill consumers, the ability to shop from home opens up new shopping opportunities and offer greater convenience (Greenstein \& Feinman, 2000:5).

In contrast, in traditional retailing, when consumers want to buy something they need to visit physical shops. Very often, they may not be able to buy the best product in the market because they visit only few shops near their home or offices. This is to some small extend modified in other forms of traditional retailing such as mail order or phone purchasing (Chan et al., 2001:12). With electronic commerce "e-commerce" shopping can be done at any time by using our "fingertips" instead of our "feet". The real gains for traditional retailers will come from leveraging the benefits of their physical presences (brick- and- mortar stores) and the benefits of their on-line presence (Turban et al., 2002: 103). The authors argue that electronic commerce "e-commerce" is attractive because it can be used to raise profit by increasing the revenue while decreasing cost. With e-commerce the business can increase revenue by exploring new opportunities and expanding into the global market Chan et al., (2001:14). However, the problem is with many companies that move from the traditional retailing to the electronic retailing but do not benefit from using it since their sales decline, or their 
website is not well designed. Shortfalls may occur because of the following; it is expensive to advertise from traditional to electronic retailing e.g. costs of connecting to the Infrastructure, internet access is still expensive and / or inconvenient for many potential customers, some have access but resist using it, they prefer the traditional way of visiting the physical shops and other reasons for not making purchases on the internet are privacy, security, and the difficulty in judging the quality of the product.

\section{The South African Context}

The inward-orientation of South African business sector has been fostered by a history of state protectionism and import -substitution industrialization during the apartheid era. Since the transition period (post 1994), however, the South African commercial industry landscape has been substantially altered by the twin pressures of globalization and the rapid liberalization of the trade policy regime, and reinforced by a major shift in state policy to open markets. South Africa has experienced rapid growth in the internet use, and is placed at number 35 by the economist Intelligence Unit's (EIU). The world's economy has been characterized by increasing globalization. Precisely what this means is that markets that span the world are now global, and everywhere large and small firms have equal access to markets that span the world. Thus, the purpose of this paper is to investigate the importance of e-commerce to small businesses in Polokwane.

The transition of the global economy from an industrial focus to one based on knowledge and information presents numerous opportunities and challenges to countries, especially those in the developing world. This new paradigm has a significant impact on the way people lead their lives. It is enabled by the use of information and communications technologies (ICTs) which have led to the compression of time and space. However, lack of infrastructure, prohibitive costs of access to infrastructure where it is available, poor quality of infrastructure, shortage of relevant skills, low levels of literacy and inadequate investment in technological developments are hindering progress toward exploiting the new generation of ICTs in developing countries. Convergence of technologies is the major driving factor that contributes to the exponential growth of electronic commerce. Convergence goes beyond the use of technology to develop new products and services and is seen as a vehicle to improve the quality of life of society in South Africa and other developing countries (Moodley S, 1998:4).

\section{Why the Green Paper on Electronic Commerce?}

The Green Paper is intended to provide a platform from which to translate topical issues around e-commerce into government policy. The Green Paper itself is not a policy document or an academic paper, but is essentially a consultative document designed to raise questions on issues that need to be addressed by the government policy formulation process. Several policy issues arise as a result of the proliferation of e-commerce. These include taxation, security and privacy, protection of intellectual property, electronic payment system, standard and interoperability. Transacting over the internet can mean, for example, that a purchaser and vendor are located at different sides of the world; a scenario, which has prompted concerns for consumer protection and the right to redress. One of the main concerns generated by e-commerce is the priority that must be accorded to issues such as privacy of personal information to safeguard public interests. Any regulatory regime that South Africa adopts must be consistent and compatible with international frameworks.

\section{The Situation of SMEs and E-Commerce in Kenya}

In the Kenyan context, small enterprises are those businesses that have 9-49 employees, whereas medium enterprises are those businesses that have 49-99 employees. Those firms which engage less than five employees are referred to as micro enterprises (Akkeren \& Cavaye, 1999:6). However, despite their contribution to job creation, SMEs in Kenya function with limited access to markets, finance and new technology. With limited access to technology, SMEs productivity remains significantly low. Through the rapid spread of information and communication technologies (ICTs), markets in different parts of the world have become more integrated. Hence, to achieve expected competitiveness, adoption of electronic commerce (e-commerce) and drivers is invaluable. For example, e-commerce is facilitated by ICT tools as the internet, World Wide Web, wireless mobile phones etc. The implementation of new technologies, use of ICT information and communication technologies and electronic commerce in SMEs provides numerous organizational opportunities. Unfortunately, despite advances in information technology and acceptance by large organizations of such technologies, the same level of adoption is not evident amongst SMEs (Knol \& Stroeken: 2001:16). 


\section{Benefits of E-Commerce to Small Businesses}

The benefits of e-commerce are not only for large firms, small and medium sized enterprises (SMEs) can also benefit from e-commerce (Chen et al., 2003:14). State that e-commerce improves an SME's ability to compete with large organizations and ultimately operate on an international scale. E-commerce is seen as a tool for providing cost-effective ways for SMEs to market their business, launch new products, improve communications, gather information, and identify potential business partners (Akkeren \& Cavaye, 1999:32). However, in spite of the many potential advantages of ecommerce, its adoption by SMEs remains limited. For example, a survey conducted by Atlas (2001:4) found that $36 \%$ of small businesses established web sites to advertise and promote their business, compared to the $9 \%$ websites that are established to sell or market the products online. (Dutta \& Evrard, 1999:5) found that many SMEs appear reluctant to embrace e-commerce applications. The main reasons cited for this reluctance are, lack of awareness, lack of business opportunities, lack of strategic vision and lack of realization of benefits of e-commerce to individual SMEs.

The paper also investigated how small business firms could survive as well as grow in the global marketplace with the help of e-commerce. Therefore, it can be concluded that with the advent of e-commerce (B-2-B and B-2-C), companies are able to accomplish various objectives that would strengthen their competitive position in the global market place. Businesses conducting e-commerce on a cyberspace must also be prepared to change as the technologies and markets change, moving from static data publishing, to increased interactivity, to real time transactions, and finally to merging business processes between business partners. In addition cost is a crucial issue; adoption of a new technology is proportionately heavier for small than for large enterprises. The internet is no longer simply a better way to publish and distribute information. The investigation revealed that the computer use is not dominant.

\section{Three Pillars of Electronic Commerce}

Another electronic business model that builds on traditional market space is the three pillars of electronic commerce model by Peter fingar, at the foundation of the model is the existing market space. Three electronic pillars support open market processes: electronic information, electronic relationship, and electronic transaction. Thus, this model builds on the existing market space and utilizes electronic mechanisms as an enabler of supporting open market processes (Peter Fingar, 1998:42).

\section{Three Pillars of Electronic Commerce}

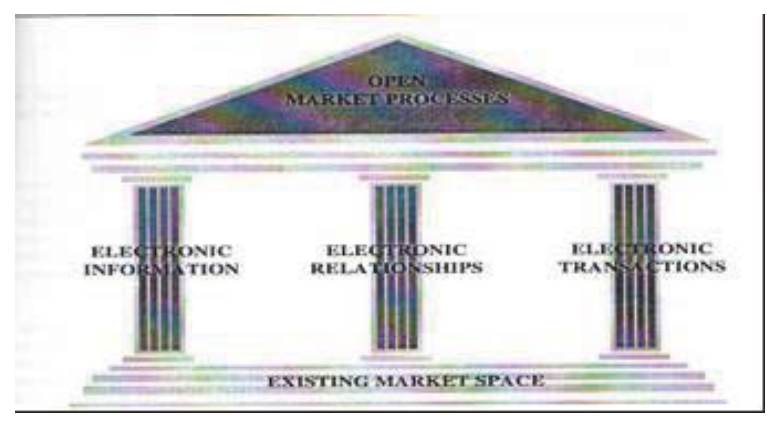

Figure1.2 (Peter Fingar, 1998:42)

The first pillar electronic information, constructing an electronic information pillar is easy: most word processing software packages will easily convert documents into a web-readable format. The challenge is to construct a good, solid pillar that will not crumble, or in WWW terms, the web page does not freeze-up or links do not lead the visitor to a dead-end or having them wandering through a maze of links without easily finding the necessary information.

The second pillar, electronic relationship, is the central pillar; the electronic pillar is about building a site that has the feeling of being a "port of entry" into a community. Having entrants pass through this port of entry on a somewhat regular basis is the key to successful engaging in electronic commerce. In order to attract users over and over again to a site (which also means away from other sites), the site needs to have certain features; it must be innovative, add value, provide information and interaction not otherwise available, and create forums for opinion-building activities (Peter Finger, 1998:43) 
The third pillar is electronic transaction pillar, many businesses have built an electronic information pillar and some have built or are building the electronic community pillar, but substantially fewer have constructed the electronic transaction pillar. Two impediments to constructing the pillar exist: the ability to engage in meaningful and sufficient negotiation processes and security of transaction data.

\section{The Small Business Challenge}

Electronic-retailing is no panacea "something that will solve all problems" - it offers some serious challenges and tremendous risks for those who fail to provide value to the consumers, who fail to establish a profitable business model, or who fail to execute the model they establish. The road to electronic-retailing success is littered with dead companies that could not deliver on their promise. The shakeout in mid to late 2000 caused many businesses to fail, but others learned and adapted.

These challenges have resulted in a variety of creative implementations of e-commerce small business strategies. Some firms attempting to launch e-commerce initiatives have "purchased quality assurance" from an external source. This has been done to maximize quality (to provide "goods" transaction experiences for their customers) at a minimum cost. It is also a strategy designed to reduce the risk of failure of an expensive independent sunk investment. One example of this strategy is an Industrial Canada sponsored site called a "Community Storefront Marketplace" (www.communitystorefront.com/main.shtml). This site can be accessed via a government of Canada Web page and contains logos of established trusted and prominent businesses. Small businesses (and charity fund raisers) across Canada therefore small businesses can pay a fee to be part of the community Storefront Marketplace.

\section{Methodology}

The study used a quantitative approach. A designed questionnaire that was on the importance of e-commerce was distributed to small businesses in Polokwane. 100 questionnaires were distributed out to small business and 60 questionnaires were returned. Primary data was collected from Polokwane which is situated at the Limpopo province in South Africa. The charts were used to display a vast array of data in a brief and clear format. The questionnaire was divided into three sections: Section A and B was made up of Demographic questions of multiple questions with single answers and section $C$ was made of discussion questions. At the end of the questionnaire there was a room for comments for those respondents who may feel irritated by the restrictions to particular responses, which may not suit their unique situations. The paper used simple calculations for closed questions of section A and B in section $C$ the attitude was positive, for example, it was really interesting to learn that $73 \%$ of the respondents feel that Polokwane will grow much more in ten years down the line with significant contribution of e-commerce.

\section{Findings of the Study}

\section{Small Business and the Level of Education}

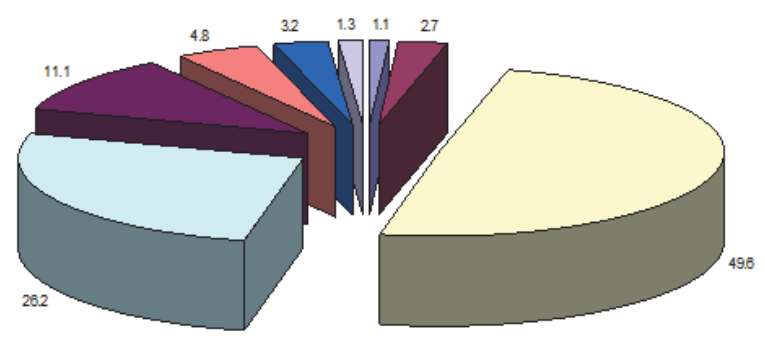

\section{Figure 4.1}

The majority of respondents (49.6\%) were having matric. The second largest respondents have a diploma (26.2\%) The 
researcher discovered that most entrepreneurs and their employees prefer to do short courses and just abreast themselves with the current information as it is needed by the e-commerce business they are operating. The third largest were those in possession of a junior degree (11.1\%). Lastly, the respondents in possession of the post graduate qualifications consisting of honours, masters and doctoral degrees is (13.1\%.) These were the findings for question 1 on the questionnaire. It is evident from the figure above that only a few percent are in possession of junior degrees, The are others who also possess postgraduate qualifications but don't stay long in small businesses as they are looking for something bigger or challenging which often falls outside the small business sector.

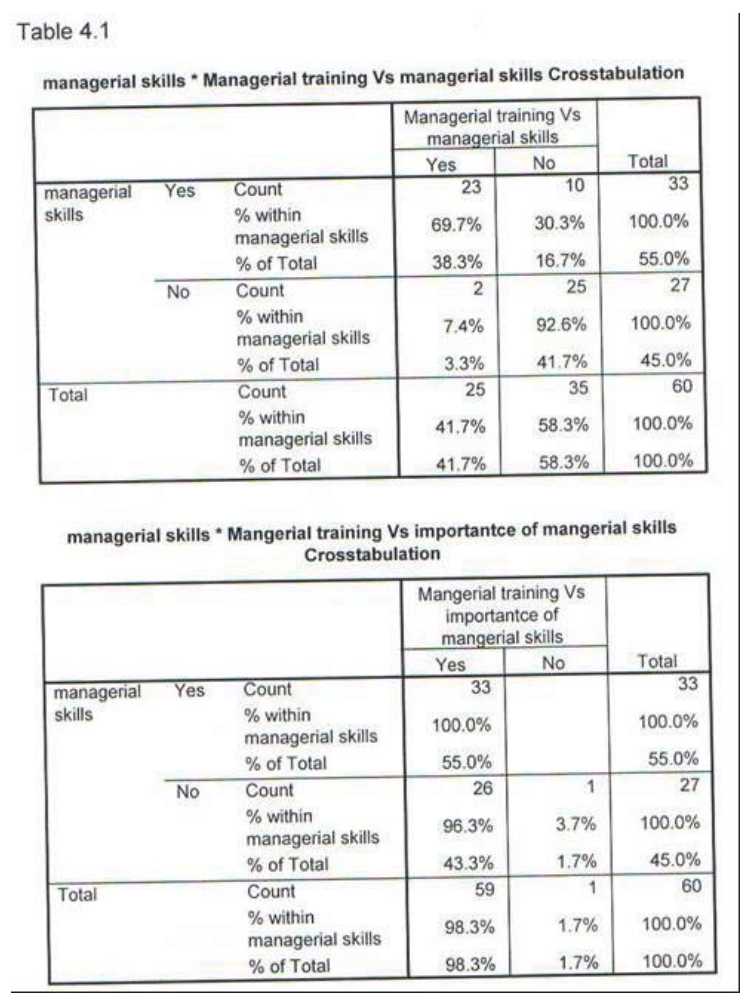

According to the table $4.1,55 \%$ of the respondents have managerial skills and $45 \%$ don't have managerial skills. About $42 \%$ of the total respondents have done managerial studies whereas the largest proportion of the respondents, 58\% never done any managerial studies before. $98 \%$ of the respondents revealed that a managerial skill is an important component to good entrepreneurial material. Only $2 \%$ of the respondents argued against the vast majority. These were the findings for Question 2 on managerial skills in the questionnaire. It is evident that large percent of the respondents believe that managerial skills are important to be a successful entrepreneur. In the opinion of the researcher this is because in electronic commerce business, the entrepreneurs have to continually equip themselves with the latest technological developments and managerial skills in order to manage their electronic businesses effectively, since ecommerce is littered with dead companies that could not manage their websites or online businesses.

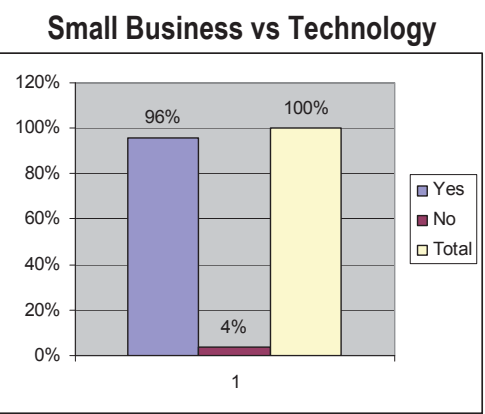

\section{Figure 4.2}


It is evident from the results in figure 4.2 that around $96 \%$ of the respondents feel that technology has got an impact on the way business is conducted today and about $4 \%$ said that technology does not have an impact on the way business is conducted today. The above findings relate to Question 3 on the questionnaire. This is because most businesses have created their electronic business that enables customers to buy at anytime and from any destination even overseas. Those who feel it has no impact is because they have tried it and failed or they know that some customers still prefer to go to the shops and get a catalogue and then buy whatever they want.

\section{Small Business vs Technological Development}

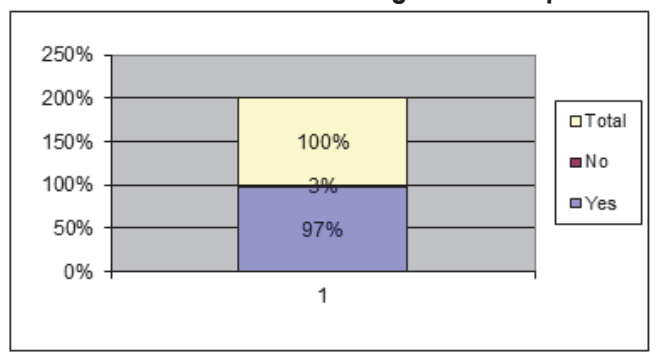

\section{Figure 4.3}

Figure 4.3 shows that $97 \%$ of entrepreneurs says they do keep themselves up to date with recent technology, however on the contrary the other $3 \%$ said they don't. In the opinion of the researcher $97 \%$ of the respondents know the importance of technology that is why they keep themselves up to date with recent technological developments. The other $3 \%$ are content with the basic technology knowledge they have.

Small Business vs Significance of Technology

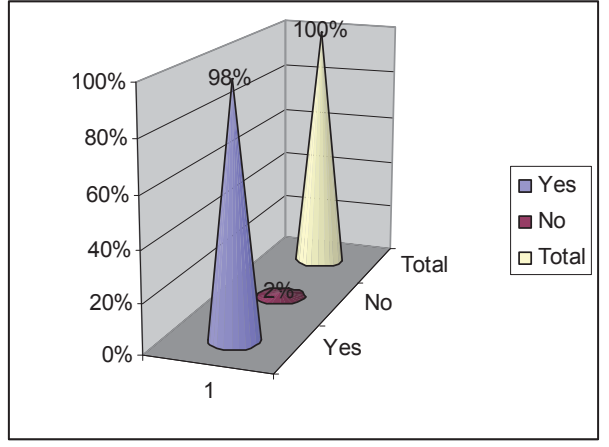

\section{Figure 4.4}

It is evident from the figure 4.4 that the total sample responds of $98 \%$ indicated that technology is essential to them while $2 \%$ stated they can live without it since they believe it's not essential. The reason why $98 \%$ stated that technology is significant to them is because they are aware that since they have started using e-commerce their sales have improved, because the respondents would not say something is important to them without seeing its benefits. The other $2 \%$ stated that it is not important because they don't know anything about it.

Small Business vs Internet Advertising

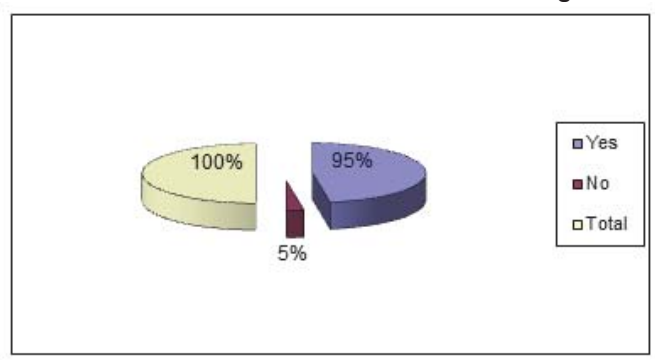

Figure 4.5 
Figure 4.5 indicates that $95 \%$ of the respondents, which is the majority of the respondents, advertise their products on line. Whereas $5 \%$ of the respondents do not advertise their products on line, which means they still use the traditional way of advertising in order to sustain their businesses.

\section{Small Business vs E-Commerce}

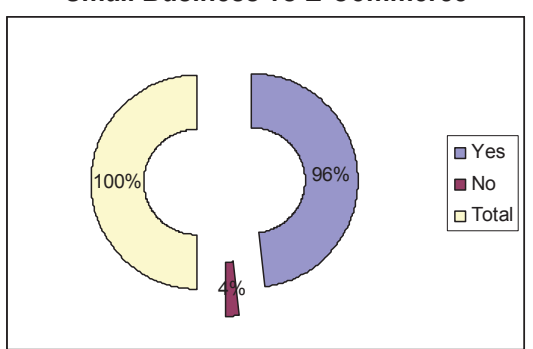

\section{Figure 4.6}

Figure 4.6 states that $96 \%$ of small businesses are selling their products on line or they are using e-commerce. Only $4 \%$ of small businesses which is the smallest percentage are not selling on-line, or they have not designed their website yet. This might be due to lack of funding and the difficulty in starting the electronic business because of the high costs of connecting to the net.

Table 4.2 South African telecommunication

\begin{tabular}{|c|c|c|c|c|}
\hline & Frequency & Percent & Valid Percent & Cumulative Percent \\
\hline Valid Yes & 54 & 90.00 & 90.00 & 90.00 \\
No & 6 & 10.00 & 10.00 & 100.00 \\
Total & 60 & 100.00 & 100.00 & \\
\hline
\end{tabular}

Table 4.2 indicates that, $90 \%$ of the respondents agree that South African telecommunication is favorable for entrepreneurial activities while about $10 \%$ of the same respondents said that, South African telecommunication is not favorable for entrepreneurship. This is because starting an electronic business is very expensive due to the cost of connecting to the infrastructure. In addition, Telkom as a true bandwagon of electronic commerce is not supportive.

Sales and E-Commerce

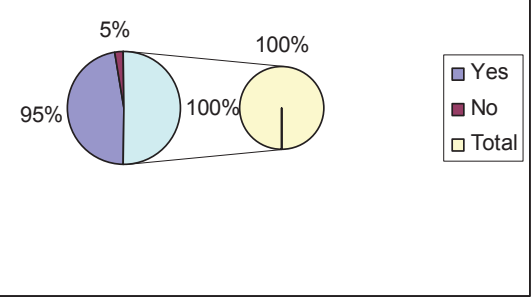

Figure 4.7

Figure 4.7 shows that $95 \%$ of the respondents agreed that their sales have increased, while $5 \%$ said theirs have dropped. It is evident that most of the electronic businesses have realized an increase in sales since they have started using ecommerce. It is evident that they have implemented their on-line businesses properly and for those who experienced a fall in sales was due to an improper establishment. 


\section{Physical vs Electronic Retailing}

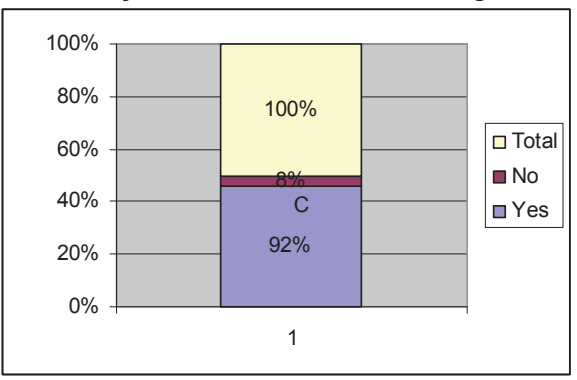

Figure 4.8

The figure above shows that respondents who use both the physical and the electronic way of doing business are 92\%, whereas those who use only physical or either the electronic way is $8 \%$. It is evident from the results in the above figure that the majority of the respondents use both the traditional and the electronic way of doing business. This safely tells you that electronic commerce should be used as a complement not as a substitute of doing business, in order for businesses to have something to fall back on if the on li business fails. The other reason why e-commerce has to be used as a complement is because not all customers have computers.

Number of Years in e-Commerce

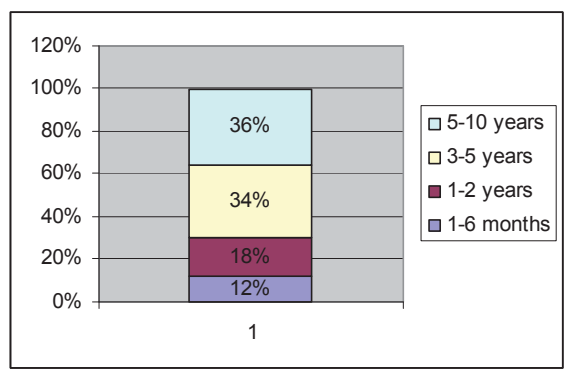

\section{Figure 4.9}

The figure presented above help in presenting the results for the question that was distributed to the respondents who were divided into four categories of years in e-commerce industry or business. Figure 4.9 shows that $36 \%$ indicates the longest period which is 5-10 years that small businesses have been engaged in e-commerce, the second largest is $34 \%$ which stands for those who have been involved in e-commerce for 3-5 years. The shortest time in which small businesses have conducted their e-commerce practices is 1-2 years and 1-6 months for those who are still emerging their e-commerce or on-line businesses are denoted by $12 \%$. It is evident that the majority of businesses have already established their e-commerce business whereas only small percentages are yet to come.

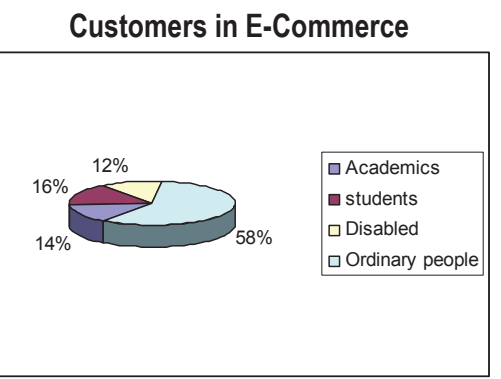

Figure 4.10

This figure reflects overall number of customers who are using the services of e-commerce, of which $58 \%$ are ordinary customers, $16 \%$ consists of students then followed by $14 \%$ which is made of academics and lastly $12 \%$ which consists of disabled customers. The majority is made up of ordinary people mainly the working class with resources, they are able to shop from their offices because the shopping is only a finger tip away. 
E-commerce and Entrepreneurial Success Factors

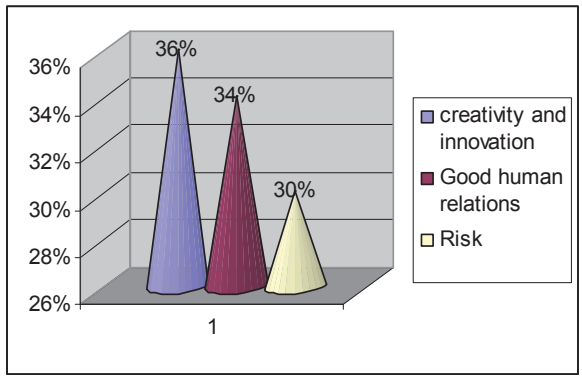

Figure 4.11

The above figure states that $36 \%$ of respondents believe that successful entrepreneur needs to be creative and innovative to sustain their on-line businesses. $34 \%$ of respondents argue that an entrepreneur needs to have good human relations to run their on-line business effectively. Lastly $30 \%$ believe that to be a successful entrepreneur one has to take calculated risk because the future is always not predictable.

Table 4.3: Future of polokwane in 10 years time

\begin{tabular}{|l|c|c|c|c|}
\hline & Frequency & Percent & Valid Percent & Cumulative Percent \\
\hline Valid develops much more & 44 & 73.3 & 73.3 & 73.3 \\
Steady growth & 4 & 6.7 & 6.7 & 80.0 \\
Not answered & 12 & 20.00 & 20.00 & 100.00 \\
Total & 60 & 100.00 & 100.00 & \\
\hline
\end{tabular}

Table 4.3 indicates that $73 \%$ of the respondents agreed that Polokwane will develop much more. Whereas about $7 \%$, agreed that Polokwane will have a steady growth. $20 \%$ were undecided.

Table 4.4: The overall importance of e-commerce to small businesses

\begin{tabular}{|l|c|c|c|c|}
\hline & Frequency & Percent & Valid Percent & Cumulative Percent \\
\hline Economic growth & 8 & 13.3 & 13.3 & 13.3 \\
\hline Job creation & 1 & 1.7 & 1.7 & 15 \\
\hline Global reach & 25 & 41.7 & 41.7 & 56.7 \\
\hline Excellent tool to use & 2 & 3.3 & 3.3 & 60 \\
\hline Saves time and money & 20 & 33.3 & 33.3 & 100 \\
\hline Not answered & 4 & 6.7 & 6.7 & 100 \\
\hline Total & 60 & 100 & & \\
\hline
\end{tabular}

With regard to the question on the overall importance of e-commerce to small businesses, the largest percentage of respondents perceived the global reach as the most important element of e-commerce to small businesses by $41.7 \%$. The second largest percentage is $33.3 \%$ as respondents stated that e-commerce saves people's time for visiting traditional shops as they can always buy on the internet from their offices and home. Economic growth is $13.3 \%$ as they have stated that it is important in the sense that it will increase the economic growth of the business if managed effectively. It is therefore an excellent tool to use.

Table 4.5: Challenges facing small businesses using e-commerce

\begin{tabular}{|l|c|c|c|c|}
\hline & Frequency & Percent & Valid Percent & Cumulative Percent \\
\hline Valid corruption & 1 & 1.7 & 1.7 & 1.7 \\
\hline Lack of black Empowerment & 2 & 3.3 & 3.3 & 5.0 \\
\hline Crime & 2 & 3.3 & 3.3 & 8.3 \\
\hline Discrimination & 2 & 3.3 & 3.3 & 11.7 \\
\hline Resources & 8 & 13.3 & 13.3 & 25.0 \\
\hline NIP & 40 & 66.7 & 66.7 & 91.7 \\
\hline Not answered & 5 & 8.3 & 8.3 & 100.0 \\
\hline Total & 60 & 100.0 & 100.0 & \\
\hline
\end{tabular}


Table 4.5 indicates that, small businesses using e-commerce stated that $13 \%$ of the total sample believes that resources are the main problem encountered, such as financial constraints, Telkom as the true bandwagon used for e-commerce is not that much effective. Where as there are certain percentages which is about 3.3\% of the respondents feel that lack of black empowerment, crime, discrimination are also problems faced by small businesses. In the opinion of the researcher, there are still lots of problems in the easily accessing of information, service intangibility which is the difficulty in judging the quality of the products, fraudulent cards is a challenge as well and lastly, most businesses that are using e-commerce are mostly owned by white people as compared to those that are operated by the black people.

Funding and paying for the use of e-commerce might also be a problem because most of the small businesses are not making enough profit. Therefore, it is recommended that resources should be made available to the businesses using e-commerce. It is also important to give professional guidance and support for those who are already in business and motivate those who desire to start their own on-line business

\section{E-Commerce as a Substitute or Complement of the Traditional Way of Doing Business}

\section{Figure 4.12}

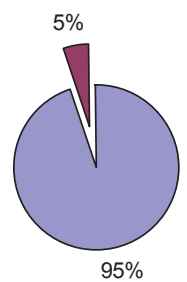

$95 \%$

Figure 4.12 Shows $95 \%$ as the largest number of respondents that says it e-commerce should be used as a complement not as a substitute of the traditional way of doing business. On the other hand, $5 \%$ which is the lowest percentage says it should be used as a substitute not as complement of the traditional way of doing business. Most of the respondents said it is crucial for businesses to have the traditional business in case the electronic one fails. Others said it should not substitute the traditional way of doing business because other business do not have access to computers and infrastructures of doing online business.

\section{Problems Experienced during the Research}

In some cases it was difficult to find the responsible person usually the owner or manager of the business and as a result the employees refused to give the information. In some businesses managers were too busy to fill in the questionnaires as a result the questionnaires were left for completion during a spare time. During a follow-up with the business concerned, the researcher would find that the questionnaires have not yet been completed.

\section{Concluding Remarks}

Based on the findings of the study, it is highly recommended that small business should use e-commerce in marketing their services. This way they will be able to grow their businesses and participate in the global economy. Results reveal that high cost, limited funds and lack of technical know-how are barriers in the importance of e-commerce to small businesses. It can be concluded that e-commerce is important and prominent in the survival of small businesses in Polokwane. From the study the response was positive and the enthusiasm was evident. The study therefore suggests that future research be taken on SMEs business models and adoption of e-commerce drivers such as the internet and the World Wide Web as enablers of e-commerce. Recommendation with regard to managerial skills, as reflected in crosstabulated data, the majority of respondents have both the skills and knowledge, the rest have the skills but did not do any managerial related studies. The paper recommends that the department of business management of the University of Limpopo should provide adequate training and development for these small and macro businesses in Polokwane area, it can achieve this by sending the third year students to help these small business because they will in turn helping their student in gaining exposure to the applications of Business Management and its relevancy in the real world situation. Regarding telecommunication, as indicated in the interpretation of data majority of the respondents agreed that, the 
South African telecommunication is generally favorable for entrepreneurial activities. It can therefore be generalized that South African telecommunication plays a vital role in motivating entrepreneurs and those who are entrepreneurial material. In this regard, the research recommends that further improvement in South African infrastructure must make it more favorable for those who are in Polokwane and the surrounding cities

It is evident from the results on the bar charts that respondents agree that technology has got an impact on the way business is conducted. Even those who are not entrepreneurs also agree that technology has an essential impact on the way business is conducted. Entrepreneur should also support the importance of technical knowledge. Generally, respondents agree with the importance of technological skills even if they are not entrepreneurs themselves. Therefore, the paper suggests that technological skills are essential in conducting an e-commerce business and as indicated by the majority, keeping up with the recent technology and having technological skills are one of the main criteria to have a successful electronic commerce business. Again, those who lack technical know-how need to be given enough training and motivation to keep them up to date with the latest technology and fund them to use the latest technological developments. Moreover, the paper suggests that entrepreneurs and their employees should be encouraged to participate in both local and international seminars, workshops and conferences that will broaden their knowledge and skills. This will in turn enable the entrepreneurs to cope with modern technology, new trends and recent developments.

It is evident from the results that the majority of businesses have both electronic and physical businesses. The research recommends that businesses should have both types of businesses since the electronic business should not substitute the traditional way of doing business. The physical business should be used as a backup in case the electronic one fails. However, electronic retailing is no panacea-it offers some serious challenges and tremendous risks for those who fail to provide value to the customers, who fail to establish a profitable business model, or who fail to execute the model they have established (Michael Cant et.al, 2002:20). Web sites that delay or frustrate consumers will not experience a high sales volume due to the high percentage of abandoned purchases.

\section{References}

Akkeren and Cavaye (1999). Perspectives on Technology. Cambridge University Press, Cambridge. Belch and Belch (2004). Advertising and Promotion. Sixth Edition, McGraw-Hill/Irwin, United States. Cant, M and Nel, C.G. et al., (2003). Marketing on the internet. Katherine Schowalter, United States.

Chan, H. Lee, R. Tharam, D. Chang, E. (2001). E-commerce fundamentals and applications. John Willey and Son, New York.

Dutta, S. and Evrard, P. (1999). Information technology and organization within European small enterprises European management journal, 17 (30), 239-51. York)

Fingar, P. (1998). The consultant's guide to getting business on the internet. John Willey and Sons, New York.

Gates B , Hann, S, and Otte (1995). The road ahead. Penguin Group, London.

Greenstein, L. and Feinman, C. (2000). Doing business on the internet. How to books Ltd, United Kingdom.

Greenstein, M. and Feinman T. M. (2002). Electronic commerce: security, Risk Management and Control. Jeffery J. Sheltad, United States.

Knol and Stroeken (2001). The information superhighway, Fifth edition, Prentice Hall, New Jersey.

Moodley, S. (1998). E-commerce and export markets: Small Furniture Producers in South Africa.Journal of Small Business Management1 (2): 98-101.

Turban, E. King, D. Lee, J. Warkentin, M. and Chung, M.H (2002). Electronic commerce 2002 a managerial perspective. Second Edition, Pearson education, United States. 